\title{
Determinants of Student's Entrepreneurial Intention: An Empirical Study of Entrepreneurial Education and Self-Efficacy as Predictors Variables
}

\author{
Rr. Sri Handari Wahyuningsih ${ }^{1, *}$ Arisnawati $^{1}$ \\ ${ }^{1}$ Universitas Muhammadiyah Yogyakarta, Indonesia \\ *Corresponding author. Email: handari@umy.ac.id
}

\begin{abstract}
Entrepreneurship is currently widely viewed as a breakthrough to increase the workforce's absorption for prospective graduates. This study examines the students' entrepreneurial intention (MB) determinants by focusing on the importance of entrepreneurship education (PK) (SE) as the primary predictor and self-efficacy as a mediating variable. The sample obtained was 268 students of the Faculty of Economics and Business at a private university located in the tourism center, Yogyakarta. The results showed that entrepreneurship education could increase students' intention in entrepreneurship. The results also concluded that self-efficacy plays a role as a mediating variable for entrepreneurship education on students' entrepreneurial intentions. This study implies the importance of learning materials in the curriculum that prioritizes soft skills' development to increase intrinsic motivation and self-efficacy in developing student entrepreneurial intention.
\end{abstract}

Keywords: Entrepreneurship Education, Self-Efficacy, Entrepreneurial Intention, Structural Equation Modeling (SEM).

\section{INTRODUCTION}

Based on data from Badan Pusat Statistik Indonesia in 2018, the ratio between the number of unemployed and labor force in was 6.87 million: 127.07 million people, or $5.1 \%$ of the total workforce. Besides, based on data distribution, it was revealed that the most Open Unemployment Rate (TPT) was in West Java, with $8.16 \%$, followed by Banten at $7.72 \%$ and Maluku at $7.38 \%$. The lowest unemployment percentage was in Bali with $0.86 \%$, West Sulawesi with $2.45 \%$, and Bengkulu with $2.70 \%$. This fact reinforces the importance of entrepreneurship education to enhance work independence for graduate higher education.

Entrepreneurship is a process carried out to find, evaluate, and find a product or service [23]. Meanwhile, entrepreneurship is also conceptualized as a process of creating and implementing new opportunities in complex environmental conditions and high uncertainty [9], [18]. Thus, entrepreneurship development is needed to reduce the graduates' dependence on the world of work because they can create jobs independently and even absorb new workforce. For the world of higher education in Indonesia, entrepreneurship development is in line with strategic efforts towards modern universities. Modern universities are places for developing entrepreneurial skills that can facilitate graduates' competence to create jobs.

The importance of entrepreneurship education (PK) and student entrepreneurial intentions (MB) can be studied using the planned behavior theory's perspective (1). Based on this perspective, it is revealed that intention is an essential factor that can encourage or motivate individual behavior, including student behavior. The entrepreneurial intention will encourage behavior in entrepreneurship, determined by external factors and internal factors. Researchers focused on entrepreneurship education as an external factor and self-efficacy as an internal factor.

Based on a behavioral perspective, entrepreneurial intention describes individuals' desire to create ideas, start, and develop businesses. Several studies have 
proven the entrepreneurship education's role in encouraging student intention in entrepreneurship [17], [2]. Another study has proven the self-efficacy's role in influencing student entrepreneurial intentions [13], [19]. However, several other studies have found gaps between variable relationships. Mentoor [16] conducted an experimental study to examine whether entrepreneurship education could motivate and increase intention in entrepreneurship. However, the study's results proved the opposite. Entrepreneurship education reduced entrepreneurial intention. The same study was conducted by Oosterbeek [20] which concluded the negative effects of entrepreneurship education on self-efficacy. In their study, Boyd and Vozikis [6] concluded that the higher the self-efficacy, the higher the goal setting and goal commitment. Hytti et al. [14] concluded that extrinsic motivation in entrepreneurial learning could encourage students' business ideas, while intrinsic motivation decreased students' business ideas. Farhangmehr [9] also concluded that entrepreneurship education could not encourage student entrepreneurial motivation. Students had a decreased intention in entrepreneurship during entrepreneurship training [21]. This study wants to answer this gap by using an entrepreneurial development model associated with entrepreneurship education and student self-efficacy (SE).

\section{CONCEPTUAL FRAMEWORK AND HYPOTHESIS DEVELOPMENT}

\section{Entrepreneurship Education And Student Self- Efficacy}

From the social learning theory's perspective [3], selfefficacy is seen as an individual's confidence level to show the work performance. Self-efficacy also describes a confidence degree in an individual's ability to drive motivation and stimulate cognitive abilities in achieving goals. In the entrepreneurship learning context, selfefficacy describes the confidence degree someone owns to run a business successfully. Entrepreneurship education obtained by students will provide the material understanding and strengthen their soft skills to encourage increased self-confidence in running a business. Research that proved the entrepreneurship education's importance in increasing self-efficacy was carried out by Wilson et al. [28]; Laviolette [27]; Boukamcha [5]; Farida and Ahmad [10]. Based on the description above, the study's first hypothesis is as follows.

\section{Hypothesis 1:}

Entrepreneurship education has positive and significant effect to student self-efficacy.

\section{Entrepreneurship Education Entrepreneurial Intention}

Entrepreneurial intention can be studied with a motivational approach, which describes an individual drive. Motivation describes the drive an individual has and is a strong reason to do something for a purpose. Entrepreneurial motivation can be viewed from the McClelland's Human Needs Theory concept, including achievement need, power need, and affiliation need. Research conducted by the Global Entrepreneurship Monitor (GEM) concludes entrepreneurship education's importance as a means of developing and creating jobs, increasing welfare, and creating encouraging economic growth [4]. These results are further supported by other evidence that concludes the positive effect of entrepreneurship education on entrepreneurial intentions, as Mohamad [17] concluded. Using a sample of 2300 students at the University of Utara Malaysia, the results showed that entrepreneurship education applied in higher education could encourage students' entrepreneurial intentions. Similar findings were concluded by Farida and Ahmad [10]; Badri and Hachicha [2] conducted a study using students at the University of Tunisia. The results proved that entrepreneurship education could increase student intention to become a start-up business actor. Based on the description above, the following research hypothesis was proposed.

\section{Hypothesis 2:}

Entrepreneurship education has positive and significant effect to student entrepreneurial intentions.

\section{The Role Of Self-Efficacy In Encouraging Entrepreneurial Intentions}

Self-efficacy is a positive personal aspect that can influence behavior. This aspect describes an individual's belief in his or her ability to take the actions needed to achieve results. Bandura [3] states that self-efficacy is a person's belief based on motivational, cognitive, and action aspects in carrying out behavior for a targeted outcome. The high level of self-efficacy will encourage a person's trust to succeed.

Self-confidence in entrepreneurship provides an essential contribution in encouraging students' intention in entrepreneurship. Previous researchers have conducted studies on the importance of self-efficacy. Boyd and Vozikis [6] developed the Bird's Model conceptual framework to explain the relationship between external and internal factors that drive entrepreneurial intentions. Internal factors include self-confidence. Farida and Ahmad [10] also concluded the importance of selfefficacy in encouraging students' intention in entrepreneurship. Cui et al. [8] examined the effect of entrepreneurship education on the entrepreneurial mindset. The study's results proved that students' entrepreneurial mindset was indirectly influenced by entrepreneurship education through entrepreneurial inspiration. Chang et al. [7], taking a sample of 364 
students in Taiwan, proved that cyber entrepreneurship's self-confidence could increase entrepreneurial intentions. Based on this description, the research hypothesis formulated is:

\section{Hypothesis 3:}

Self-efficacy has a significant positive effect to student entrepreneurial intentions.

\section{Mediating Role Of The Self-Efficacy}

The level of confidence to start a business is an important internal aspect that strengthens the influence of entrepreneurial education on entrepreneurial intent. The study of Zhao et al. [26], using sample of 265 business master students, proved that self-efficacy mediation has role in influencing formal entrepreneurship education to entrepreneurial intentions. In addition, the study of Laviolette [27] conducted on 276 students in France showed the role of entrepreneur model increase selfconfidence to be entrepreneur and further encourage the entrepreneurial intent of students. The same results were proven by Neto et al [19]; Shinnar et al [24]; Hsu et al. [13]; and Chang et al. [7].

\section{Hypothesis 4:}

\begin{tabular}{lcrr}
\multicolumn{1}{c}{ Self-efficacy mediate relation } & between \\
entrepreneurship & education & to & student \\
entrepreneurial intentions. & &
\end{tabular}

The model of the research can be seen in figure 1 .

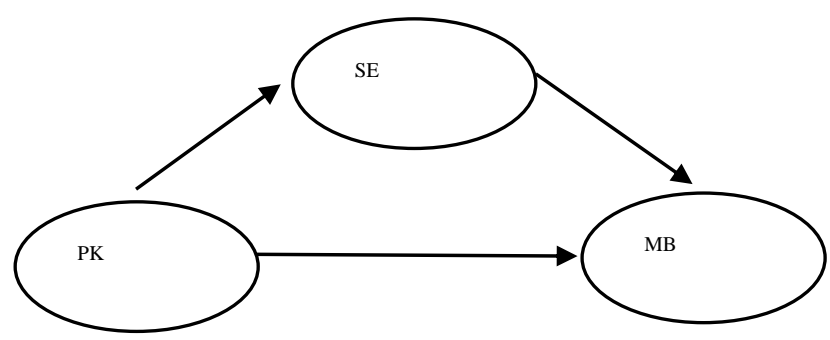

Figure.1. The Factor that influence entrepreneur intention in higher education.

\section{METHODS}

The design of this study is quantitative research. The research was carried out at students of economics and business in one of the private universities in Tourism City, Yogyakarta, Indonesia. The sampling technique employed was purposive sampling, with the criteria of students who had taken the entrepreneurship course so that they had acquired material and skills about developing business ideas. Surveys are conducted with a google form. Concretely, a participant in this study were 268 students.

The instrument of the study was developed based on previous research about entrepreneurial education (PK), self-efficacy (SE), and entrepreneurial intentions (MB).
Instrument testing was carried out using Confirmatory Factor Analysis (CFA) to test the construct's multidimensionality theoretically (12) and Construct Reliability to test the extent to which variable measurements without bias or consistently produced the same results. The results of the Confirmatory Factor Analysis (CFA) calculation showed that all question items had a loading factor value between 0.805 to 0.921 , with a significance value of $\leq 0.05$. The reliability calculation results showed that the reliability value was above> 0.70 (12) for entrepreneurship education variables (0.949), self-efficacy (0.953), and entrepreneurial intention (0.957).

\section{RESULTS AND DISCUSSION}

Descriptive statistics of data revealed high results for entrepreneurship education, self-efficacy, and entrepreneurial intention. Variable of entrepreneurship education was in the range of 4.09 to 4.35 for the five questions posed, meaning that the respondent gave a good assessment of entrepreneurship education that had been taken. Self-efficacy in starting a business was in the range of 3.85 to 4.07 for the five questions asked. Meanwhile, the value of entrepreneurial intention showed a value between 4.15 to 4.24 .

Data normality testing was performed, employing the critical ratio criteria of \pm 2.58 at a significance level of $0.01(1 \%)(12)$. The results indicated that normality was univariate normally distributed because the critical ratio value (c.r) for kurtosis (tailedness) and skewness (slope) was in the range -2.58 to +2.58 . The goodness of fit index test results demonstrated three indicators that met the criteria, namely NFI of 0.912 ; TLI of 0.919 ; and CFI of 0.933. Based on these results, it was concluded that the model was in the fit criteria.

The SEM analysis results are presented in Table 1 and produce the final model, as seen Figure 2.

Table 1. SEM Analysis Results

\begin{tabular}{|l|l|l|c|c|c|c|c|}
\hline & & Est & S.E. & C.R. & P & Result \\
\hline $\begin{array}{l}\text { Entrepre- } \\
\text { neurship } \\
\text { Education }\end{array}$ & $\rightarrow$ & $\begin{array}{l}\text { Self- } \\
\text { efficacy }\end{array}$ &, 357 &, 072 &, 964 & $* * *$ & $\begin{array}{l}\text { Positive } \\
\text { Significant }\end{array}$ \\
\hline $\begin{array}{l}\text { Self- } \\
\text { efficacy }\end{array}$ & $\rightarrow$ & $\begin{array}{l}\text { Entrepre- } \\
\text { neurial } \\
\text { Intentions }\end{array}$ &, 125 &, 053 &, 340 &, 019 & $\begin{array}{l}\text { Positive } \\
\text { Significant }\end{array}$ \\
\hline $\begin{array}{l}\text { Entrepre- } \\
\text { neurship } \\
\text { Education }\end{array}$ & $\rightarrow$ & $\begin{array}{l}\text { Entrepre- } \\
\text { neurial } \\
\text { Intentions }\end{array}$ &, 326 &, 063 &, 204 & $* * *$ & $\begin{array}{l}\text { Positive } \\
\text { Significant }\end{array}$ \\
\hline
\end{tabular}

Table 1 shows that entrepreneurship education could positively affect student self-efficacy, indicated by a probability value of $0,000(\leq 0.05)$ with a C.R value of $4,964(\geq 1.96)$. This result signified that entrepreneurship education that had been taken by students could 
encourage self-efficacy in entrepreneurship. Thus, it was concluded that the study's first hypothesis study was accepted.

The second hypothesis testing was conducted to test the effect of entrepreneurship education on students' entrepreneurial intentions. With a probability value of $0.000(\leq 0.05)$ with a C.R value of $5.204(\geq 1.96)$, it could be concluded that entrepreneurship education could encourage students' entrepreneurial intentions. Therefore, the second hypothesis was accepted. Likewise, the third hypothesis, the results illustrated a probability value of $0.019(\leq 0.05)$ with a C.R value of $2.340(\geq 1.96)$. This study's results proved that selfefficacy could encourage students' entrepreneurial intentions.

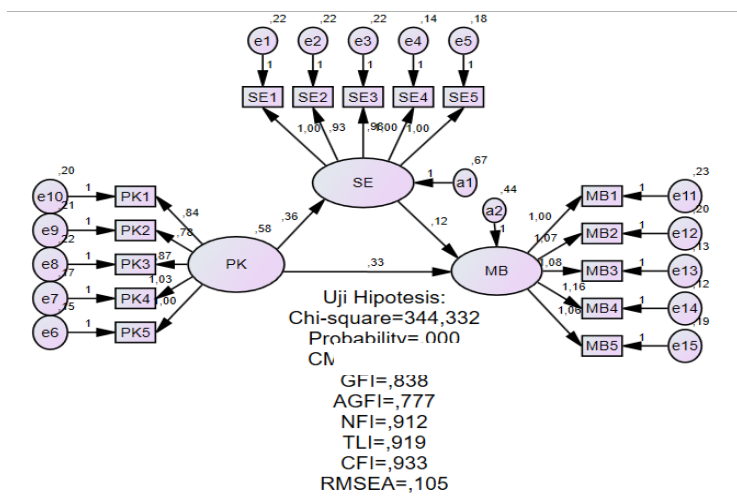

Figure 2

Full Model Estimate

To test the indirect effect of entrepreneurial education on entrepreneurial intent is carried out "sobel test". Figure 3 explains the results.

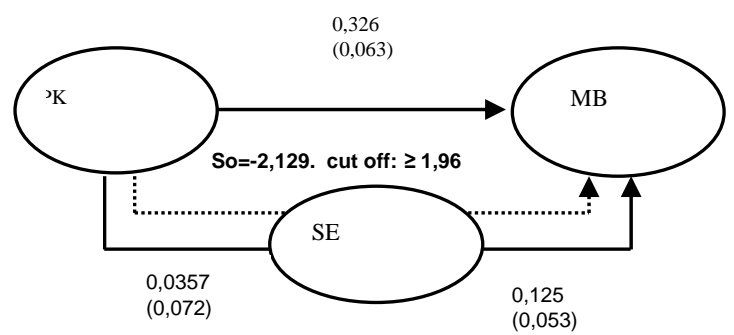

Figure 3: Indirect Effects

The results presented in figure 2 prove the role of selfefficacy in mediating the influence of entrepreneurial education on the entrepreneurial interests of students (Sobel test 2,129 ( $\geq 1.96$ ). So the fourth hypothesis is accepted.
This study proved the research hypothesis about the effect of entrepreneurship education on self-efficacy in entrepreneurship. With entrepreneurship education, students gained additional insight into entrepreneurship, gained cognitive provisions, improved soft skills, and psychomotor while attending college. The stimuli given were proven to increase strength and reduce limitations on previous experiences to encourage entrepreneurship self-confidence. The results of this study support previous research [28], [15], [5], [10], who concluded that entrepreneurship education could increase selfefficacy in starting a business.

The results also proved the importance of entrepreneurship education in encouraging entrepreneurial intention. This research provides quite important notes. From a behavioral perspective, the intention has an essential meaning in explaining behavior. Entrepreneurship intention is understood as a process that creates business ideas and desires to carry out these ideas. Students revealed that entrepreneurial intention was related to the desire to reduce dependence on the world of work, have freedom in choosing business fields, and help social problems in the environment. This research is consistent with Cui et al. (8), which confirmed entrepreneurship education's effect on the entrepreneurial mindset.

This study verified the effect of self-efficacy on students' entrepreneurial intentions. The self-efficacy's dimensions, such as the courage to start an independent business, the confidence to run a business successfully, and the courage to manage business challenges, were proven to encourage students' entrepreneurial intentions. This result is coherent with the conclusion of Chang et al. [7], Boyd and Vozikis [6], Farida and Ahmad [10] confirming that self-confidence in entrepreneurship could increase entrepreneurial intentions.

This study also proved the role of self-efficacy as a mediation for the influence of entrepreneurship education on students' entrepreneurial intentions. Entrepreneurship education that provided cognitive, psychomotor, and entrepreneurial role models could encourage student selfefficacy in running a business, thereby increasing entrepreneurial intentions. This study is following by Zhao et al. [26], Laviolette et al. [27], Neto et al. [19], Shinnar et al. [24], Hsu et al. [13], Chang et al. [7].

This study answered the research gap about the effects of entrepreneurship education in encouraging entrepreneurial attitudes and behavior. In Indonesia's higher education context, education is implemented through various strategies, one of which is through curriculum implementation. Primarily, the Education Curriculum in Indonesia has a content of strengthening knowledge and cultivating attitudes, which are nothing but the soft skills' cultivation indispensable in developing an entrepreneurial spirit. This empirical evidence 
reinforces the importance of cultivating entrepreneurial values to create new ideas and ventures in the future.

The implication of the study is the urgency of the university to attend entrepreneurship curricula, which can boost students' confidence in starting a business and increase intention in entrepreneurship. Entrepreneurship education obtained during college will instill the soft skills' spirit that leads to students' readiness to start a business, thereby increasing self-confidence and intention in starting a business. For students, the entrepreneurship education they receive will encourage their self-confidence. For this reason, an entrepreneurial curriculum development tailored to a business model development according to environmental demands is essential.

This study has several limitations. First, the generalization of the result study may only be limited to Indonesia's national territory. Second, this study has only used cross-sectional data, so it could not provide information about the long-term effects of entrepreneurship education. Finally, this study only employed two antecedents of entrepreneurial intention: entrepreneurship education and self-efficacy.

\section{CONCLUSION}

Based on the research, the writer concludes some things are: a). Entrepreneurship education has positive and significant effect to student self-efficacy; b). Entrepreneurship education has positive and significant effect to student entrepreneurial intentions; c). Selfefficacy has a significant positive effect to student entrepreneurial intentions; d). Self-efficacy mediate relation between entrepreneurship education to student entrepreneurial intentions. The next research that is suggested by the author is: 1) use a broader area to reach generalization of the study, for example, using several countries; 2) use use the longitudinal data to increase generalization and usefulness; 3 ). add the other variables, such as career intention [26], locus of control and innovation [16], family environment [10], motivation, and entrepreneurial competence [9], which can influence entrepreneurial intentions.

\section{REFERENCES}

[1] Ajzen Icek, "The theory of planned behavior," Organizational Behavior and Human Decision Processes, vol. 50, pp. 179-211, 1991.

[2] Badri, R. and Hachicha N, "Entrepreneurship education and its impact on students' intention to start-up: A sample case study of students from two tunisian universities," The International Journal of Management Education, vol. 17, pp. 182-190, 2019.
[3] Bandura A., "Self-efficacy: toward a unifying theory of behavioural change," psychological review, vol.84, pp. 191-215, 1977.

[4] Barba-Sáncheza, Virginia and AtienzaSahuquilloba Carlos, "Entrepreneurial intention among engineering students: the role of entrepreneurship education," European Research on Management and Business Economics," vol. 24, pp.53-61, 2017.

[5] Boukamcha Fayçal, "Impact of training on entrepreneurial intention: an interactive cognitive perspective", European Business Review, vol. 27, iss.6, 2015.

[6] Boyd G. Nancy and Vozikis S. George. "The influence of self-efficacy on the development of entrepreneurial intentions and actions," Entrepreneurship Theory and Practice, Summer, p.63-77, 1994.

[7] Chang Shu-Hsuan, Shu Yu, Wang Chih-Lien, Chen Mu-Yen, Ho Wei-Sho, "Does positive thinking moderate the relationship between cyberentrepreneurial self-efficacy and cyberentrepreneurial intentions in non-IT students?," Computers in Human Behavior, vol. 107, 2019.

[8] Cui Jun, Sun Junhua, and Bell Robin, "The impact of entrepreneurship education on the entrepreneurial mindset of college students in China: the mediating role of inspiration and the role of educational attributes," The International Journal of Management Education, 2019.

[9] Farhangmehr Minoo, Gonçalves Paulo, Sarmento Maria, "Predicting entrepreneurial motivation among university students: The role of entrepreneurship education," Education+ Training, vol. 58, iss: 7/8, pp.861-881, 2016.

[10] Farida Sifa, Nurkhin Ahmad, "Pengaruh pendidikan kewirausahaan, lingkungan keluarga, dan self efficacy terhadap minat berwirausaha siswa SMK Program Keahlian Akuntansi," Economic Education Analysis Journal, vol.5, no.1, pp.273289, 2016.

[11] Fayolle Alain, Gailly Beno1^t, Lassas-Clerc Narjisse, "Assessing the impact of entrepreneurship education programmes: a new methodology," Journal of European Industrial Training, vol. 30, no. 9, pp. 701-720, 2006.

[12] Ghozali Imam, "Model Persamaan Struktural Konsep dan Aplikasi Dengan Program AMOS 24," cetakan ketujuh, Badan Penerbit Universitas Diponegoro, Semarang, Indonesia, 2017. 
[13] Hsu K. Dan, Burmeister-Lamp Katrin, Simmons A. Sharon, Foo Maw-Der, Hong C. Michelle, Pipes D. Jesse, "I know I can, but I don't fit: perceived fit, self-efficacy, and entrepreneurial intention," Journal of Business Venturing, pp.1-48, 2018.

[14] Hytti Ulla, Stenholm Pekka, Heinonen Jarna, Seikkula-Leino Jaana, "Perceived learning outcomes in entrepreneurship education: the impact of student motivation and team behaviour", Education + Training, vol. 52, Issue: 8/9, pp.587606, 2010.

[15] Laviolette Michael Eric, Lefebvre Radu Miruna, Brunel Olivier, "The impact of story bound entrepreneurial role models on self-efficacy and entrepreneurial intention," International Journal of Entrepreneurial Behaviour \& Research, vol. 18, no. 6, pp. 720-742, 2012.

[16] Mentoor E.R. and Friedrich C., "Is entrepreneurial education at South African universities successful? An empirical example," Industry \& Higher Education, pp.221-232, 2007.

[17] Mohamad Noorkartina, Lim Hock- Eam, Yusof Norhafezah, Soon Jan Jan, "Estimating the effect of entrepreneur education on graduates' intention to be entrepreneurs," Education+ Training, vol. 57 Iss 8/9, pp. 874-890, 2015.

[18] Neck, H. and Greene, P. "Entrepreneurship education: known worlds and new frontiers," Journal of Small Business Management, vol. 49, no. 1, pp. 55-70, 2011.

[19] Neto Amorim do Carmo Roque, Rodrigues $P$ Vinicius, Stewart Douglas, Xiao Anna, Snyder Jenna. "The influence of self-efficacy on entrepreneurial behaviour among K-12 teachers," Teaching and Teacher Education, vol.72, p.44-53, 2018.

[20] Oosterbeek Hessel, Praag van Mirjam, IJsselstein Auke, "The impact of entrepreneurship education on entrepreneurship competencies and intentions: an evaluation of the junior achievement student MiniCompany Program," Discussion Paper Series, IZA DP, no. 3641, 2008.

[21] Piperopoulos Panagiotis, "Could higher education programmes, culture and structure stifle the entrepreneurial intentions of students?," Journal of Small Business and Enterprise Development, vol. 19, no. 3, pp. 461-483, 2012.

[22] Robbins P. Stephen and Judge A. Timothy, "Organizational Behavior," Fourteenth Edition, Pearson Education, Boston, 2016.
[23] Shane, S. and Venkataraman, S., "The promise of entrepreneurship as a field of research", Academy of Management Review, vol. 25, no. 1, pp. 217-226.

[24] Shinnar S. Rachel, Hsu K. Dan, Powell C. Benjamin, "Self-efficacy, entrepreneurial intentions, and gender: assessing the impact of entrepreneurship education longitudinally," The International Journal of Management Education, vol12, iss 3, pp.561-570, 2014.

[25] Solesvik Z. Marina, "Entrepreneurial motivations and intentions: investigating the role of education major," Education + Training, vol. 55, no. 3, pp. 253-271, 2013.

[26] Zhao Hao, Seibert E. Scott, and Hills E. Gerald, "The mediating role of self-efficacy in the development of entrepreneurial intentions," Journal of Applied Psychology, vol. 90, no.6, pp.12651272, 2005.

[27] Laviolette Michael Eric, Lefebvre Radu Miruna, Brunel Olivier, "The impact of story bound entrepreneurial role models on self-efficacy and entrepreneurial intention," International Journal of Entrepreneurial Behaviour \& Research, vol. 18, no. 6, pp. 720-742, 2012.

[28] Wilson Fiona, Kickul Jill, and Marlino Deborah, "Gender, entrepreneurial self-efficacy, and entrepreneurial career intentions: implications for entrepreneurship education," Entrepreneurship Theory and Practice, pp.386-406, 2007. 